\title{
Effects of Weathered Soil Parent Materials on Merlot Grapevines Grafted onto 110 Richter and 101-14Mgt Rootstocks
}

\author{
J. Wooldridge*, M.P. Olivier
}

ARC Infruitec-Nietvoorbij ${ }^{1}$, Private Bag X5026, 7599 Stellenbosch, South Africa

Submitted for publication: August 2013

Accepted for publication: January 2014

Key words: Coastal region, granite, kaolinite, potassium, shale, Western Cape

\begin{abstract}
In a trial under semi-controlled conditions, Merlot grapevines on 101-14Mgt and 110 Richter (110R) rootstocks were grown in virgin soils developed in highly weathered parent materials derived mainly from granite and metasediment (shale). Each soil was irrigated at c. $-\mathbf{0 . 0 7 5} \mathrm{MPa}$. The clay fractions of both soils were dominated by kaolinite. Lime and $\mathrm{P}$ were supplied, but no $\mathrm{K}$. Bray II soil $\mathrm{K}$ levels from both parent materials were similar in the field state, but lower in the shale than in the granite when averaged over the trial period. Petiole $\mathrm{K}$ concentrations did not differ between rootstocks on the granite, but on the shale soils were higher in the vines on 101-14Mgt than on 110R. The granite $x$ 101-14Mgt treatment significantly promoted $(p \leq 0.05)$ greater trunk circumferences, cane mass, leaf areas and overall wine quality than the shale $x$ 110R treatment. Yields from grapevines in the granite $x$ 110R and granite $x$ 101-14Mgt treatments did not differ significantly. However, the granite $x$ 101-14Mgt treatment produced higher yields than the shale $x$ 101-14Mgt and shale $x 110 \mathrm{R}$ treatments. These differences were attributed to an interaction between the soil and rootstock, with $\mathrm{K}$ availability and uptake as contributory factors.
\end{abstract}

\section{INTRODUCTION}

Soil affects viticulture through its effects on soil strength, water availability and nutrient delivery (Van Zyl, 1988, and references therein). Where transport of superficial material is minimal and weathering has not been severe, soil texture and mineralogy may reflect the underlying rocky material (geology, sensu lato). Geology, in these cases, may be a useful factor in vineyard demarcation. However, the landscapes and soils of the viticultural areas of the Western Cape are products of sub-aerial weathering processes that both pre- and post-dated the fragmentation of Gondwana in the Cretaceous, the massive erosion that followed, and wide variations in climate and sea level (Partridge \& Maud, 1987; Söhnge, 1991). Warm and humid to wet conditions prevailed for much of the Tertiary. These promoted intense chemical weathering, characterised by the partial or complete break-down of susceptible primary minerals, base loss, acidification, and clay mineral neoformation, notably of kaolinite (Söhnge, 1991). These changes locally extended to depths of tens of metres (Lambrechts, 1983). Whether soils developed on such highly weathered material retain sufficient of the characteristics of the original parent rock to cause geology-related differences in grapevine growth and wine characteristics, and to be useful for demarcation purposes, is unclear, but may be possible in lithic soils (soils that retain their lithic character after weathering (Fey, 2010).

The Stellenbosch, Paarl and Malmesbury wine districts of the Western Cape are located on the western coastal foreland, jointly contain c. 47000 ha of mostly red grape varieties (Floris \& Uren, 2011), and are underlain by granitic intrusives and metasedimentary country rock, commonly known as shale (Theron et al., 1992). Fresh granites contain quartz, feldspar and mica. Feldspar is broken down by carbonic acid from rain, releasing $\mathrm{K}$. Under severe weathering conditions, kaolinite, a near chemically-inert clay mineral, may form from weathering products (Wilson, 1999). Micas (sheet silicates) also occur in metamorphic rocks, such as shale (Bühmann et al., 2004a, 2004b). On weathering, mica degrades into interstratified forms such as chlorite and vermiculite, releasing $\mathrm{K}$ in the process (Wilson, 1999). These, in turn, may degrade to form smectites and, finally, kaolinite. Smectites are a group of expanding, waterretaining clay minerals with high cation exchange capacities. Even after intense weathering, granite-derived soils may retain sufficient feldspar and mica in the coarser fragments to provide a limited supply of poorly buffered K (Wooldridge, 1990). However, in the shale soils of the western coastal foreland, most of the original mica structures have degraded and their constituent $\mathrm{K}$ has been lost (Bühmann et al.,

\footnotetext{
${ }^{1}$ The Fruit, Vine and Wine Institute of the Agricultural Research Council
}

*Corresponding author: e-mail address: wooldridgejo@arc.agric.za

Aknowledgements: We would like to thank Winetech for partial funding, the ARC for resources, and our colleagues at the ARC Infruitec-Nietvoorbij, for technical and specialist support 
2004b). Shale soils may nevertheless have the capacity to fix applied (fertiliser) $\mathrm{K}$ where layer structures persist (Bühmann et al., 2004b), or to provide a sufficient degree of buffering to reduce luxury consumption and loss through leaching (Wooldridge, 1988). The ability to supply, or fix, limited amounts of $\mathrm{K}$ therefore is a soil characteristic that may differ between conferred mineral assemblages in soils even after severe weathering.

Potassium is both an osmoticum and an enzyme cofactor (Mengel \& Kirkby, 2001). Acidity in wine reflects the balance between $\mathrm{K}$, malic acid and tartaric acid (Deloire, 2010). High juice K increases wine pH (Iland, 1988), resulting in increased spoilage, poor colour and a flat taste (Mpelasoka et al., 2003). Conversely, K deficiencies result in poor overall plant performance (Mengel \& Kirkby, 2001). Tissue $\mathrm{K}$ concentrations in grapevines vary with soil K availability. They also vary between grapevines on rootstocks of different genetic derivations. Petiole K levels at bloom in grapevines on rootstocks that include Vitis berlandieri in their parentage, such as $110 \mathrm{R}$, tend to be lower than in grapevines on rootstocks derived from $V$. champinii. Petiole $\mathrm{K}$ levels in grapevines on $\mathrm{V}$. riparia $\mathrm{x} V$. rupestris rootstocks, notably 101-14Mgt, are usually intermediate between extremes represented by hybrids of $V$. berlandieri and $V$. champinii (Wolpert et al., 2005). Scion responses to differences in $\mathrm{K}$ availability therefore are likely to differ between combinations of soil and rootstock.

According to Van Schoor (2001), grapevine growth and wine character in the areas around Stellenbosch and Durbanville are not linked to parent rock type, but respond instead to differences in the abundance and proportions of rock-weathering products, which in turn may be related to altitude. Increases in kaolinite content were associated with decreased vegetative growth and overall wine quality, whereas overall quality improved with increasing clayfraction quartz content. Quartz content increased, and kaolinite content decreased, with increasing altitude. Shange (2009) found that the effects of geology on K nutrition and vine performance in vineyards in the Helderberg area were inconsistent and obscured by cultural variables such as fertiliser usage, soil preparation, rootstock, scion clone and grapevine age.

To further investigate the effects of contrasting, highly weathered soil parent materials on grapevine performance and wine quality, a trial was carried out in which Merlot grapevines on two genetically distinct rootstocks were grown on soils developed in parent materials derived mainly from the in situ weathering of granite, and of shale. The trial was carried out under semi-controlled conditions to minimise environmental variables.

\section{MATERIALS AND METHODS}

Bulk samples of two soils with their constituent lithic (> $2 \mathrm{~mm}$ ) materials were excavated to a depth of ca. $55 \mathrm{~cm}$ of two Glenrosa soils (orthic A grading into lithocutanic B; Soil Classification Working Group, 1991) at the Nietvoorbij Research Farm of ARC Infruitec-Nietvoorbij, near Stellenbosch. Stellenbosch has a Mediterranean climate and falls in Winkler region IV (Bonnardot et al., 2011). Both soils were located on the crest of a deflating, semi-isolated ridge.
The sites were covered by bush, with no known history of cultivation, or of lime or fertiliser application. One of the soils, located at $33.9172^{\circ} \mathrm{S}, 18.8689^{\circ} \mathrm{E}$, altitude $216 \mathrm{~m}$, was underlain by weathered, kaolinitised Namibian-era Tygerberg Formation (Malmesbury Group) metagreywacke (shale) (Theron et al., 1992). The second soil had developed slightly higher up the ridge, at $292 \mathrm{~m}$, on weathered granite of the Stellenbosch pluton (Cape Granite Suite) at $33.9093^{\circ} \mathrm{S}$, $18.8730^{\circ} \mathrm{E}$. Both soils had developed in situ. Small amounts of quartzitic sand from the former Peninsula formation cover, or wind-transported from the Quaternary drift deposits of the coastal lowlands, may also have been present.

The mainly granite, and mainly shale-derived soil materials, were transported to the Infruitec Campus of ARC Infruitec-Nietvoorbij near Stellenbosch (33.9231 ${ }^{\circ} \mathrm{S}$, $18.8746^{\circ} \mathrm{E}$, altitude $\left.135 \mathrm{~m}\right)$, analysed, and loaded into $3.0 \mathrm{~m}$ long x $1.5 \mathrm{~m}$ wide x $1.5 \mathrm{~m}$ deep compartments in a 24-compartment concrete structure (a former drainage lysimeter). Sufficient dolomitic and calcitic lime, and single superphosphate $(10.5 \% \mathrm{P})$, calculated by the methods of Conradie (1994) and Kotzé (2001), were forked into the soils during filling to bring the $\mathrm{pH}$, exchangeable acidity and Bray II extractable soil P (BP) concentrations of both soils to 5.9, $0.25 \mathrm{cmol}(+) / \mathrm{kg}$ and $32 \mathrm{mg} / \mathrm{kg}$ respectively, after settling but before planting in 2004. Each free-draining compartment was floored with permeable geotextile over coarse gravel.

Composite soil samples (0 to $30 \mathrm{~cm}$ and 30 to $60 \mathrm{~cm}$ depth intervals) were obtained by auger during August from 2006 to 2011. Maintenance lime requirements were calculated for each soil and applied annually in September. No K was provided. Nitrogen was supplied as limestone ammonium nitrate $(28 \% \mathrm{~N})$ in accordance with Conradie (1994). Routine sprays for fungal diseases and pests were applied in accordance with normal industry practice. The grapevines were irrigated using a pressure-regulated microsprinkler irrigation system fitted with two c. $30 \mathrm{~L} / \mathrm{h}, 70 \mathrm{~cm}$ radius emitters per compartment. The soils were irrigated separately, at matric potentials $\left(\Psi_{\mathrm{M}}\right)$ between -0.07 $\mathrm{MPa}$ and -0.08 MPa determined with Bourdon tensiometers (six per soil) at $60 \mathrm{~cm}$ depth. Sufficient municipal water was applied to restore the soil water content to field capacity $\left(\Psi_{\mathrm{M}}=0.00 \mathrm{MPa}\right)$.

\section{Grapevines, sampling and leaf water potentials}

Two grafted Merlot grapevines, one on 101-14Mgt (Vitis riparia $\mathrm{x} V$. rupestris) and the other on 110 Richter (110R) ( $V$. berlandieri $\mathrm{x} V$. rupestris) rootstock, were planted in random sequence in each compartment during August 2005. The grapevines were spaced at $1.75 \mathrm{~m}$ intervals in $1.5 \mathrm{~m}$-wide double rows with $4.0 \mathrm{~m}$ between double rows (2 079 vines/ha). An $80 \%$ shade cloth windbreak was located $10 \mathrm{~m}$ upwind of the structure. Single shoots were trained onto the cordon wires of an extended vertical trellis system (cordon plus three pairs of movable wires) in spring 2006. Commencing in winter 2007, the grapevines were pruned to a single two-bud spur per $15 \mathrm{~cm}$ of cordon length. All vertical shoots were cut back to $40 \mathrm{~cm}$ above the top trellis wires after hardening. Cane mass, number of canes per grapevine and trunk circumference were determined during 
pruning in July of each season. Leaf areas and leaf numbers per shoot were measured in autumn, before leaf fall. Number of leaf layers in the canopy (point quadrat method) were also measured in autumn. Leaf areas were measured with an automated and calibrated leaf area meter (LI-COR 3100). Leaf (blade and petiole) samples were taken for analysis at fruit set. Leaf water potentials $\left(\Psi_{L}\right)$ (one mature leaf from each vine) were measured before dawn (c. 04:00) and at midday (c. 13:00) of the same day, approximately 10 days before harvest in 2010, 2011 and 2012, using the pressure vessel technique (Scholander et al., 1965, as adapted by Myburgh, 2010). Values for $\Psi_{M}$ were recorded shortly before the midday $\Psi_{\mathrm{L}}$ determinations.

\section{Grape harvest}

To promote rapid structural development during the first bearing season (2007/08), all bunches except one bunch per spur were removed when the berries reached pea size. The grapes from each vine were harvested separately, at c. $24^{\circ}$ Balling in early February in years 2008 to 2012 . The number of bunches per grapevine, bunch mass, number of grapes per bunch and single grape mass (without trunk) were also determined. The harvested grapes were covered and transported to the ARC cellar at Nietvoorbij Research Farm. Grapes from the six vines in each soil x rootstock treatment were combined before being pressed.

\section{Soil and leaf analyses}

Soil samples were subjected to routine soil analysis. Acidity $(\mathrm{pH})$ and titratable acidity $(1 \mathrm{M} \mathrm{KCl})$ were determined in accordance with the Non-Affiliated Soil Analysis Work Committee (1990), as were ammonium acetate (0.2 M, $\mathrm{pH}$ 7), exchangeable $\mathrm{Na}, \mathrm{K}, \mathrm{Ca}$ and $\mathrm{Mg}$, and cation exchange capacity (CEC). The T-values (sums of exchangeable $\mathrm{Na}, \mathrm{K}, \mathrm{Ca}, \mathrm{Mg}$ and acidity) were calculated. Soil P and K were determined by the $0.03 \mathrm{M}$ ammonium fluoride in $0.01 \mathrm{M}$ hydrochloric acid extraction method of Bray II. Element concentrations were quantified using a Vista MPX inductively-coupled plasma atomic emission spectrograph (ICPAES). Soil textures were ascertained by the sieve and hydrometer method. Clay minerals were identified, and then quantified in relative terms by the ARC Institute for Soils, Climate and Water using X-ray diffraction analysis and preparation methods derived from Alexiades and Jackson (1966).

Particles in the sand grades were identified microscopically. The leaf blade (lamina) and petiole samples were washed separately, dried in a forced draught oven at $70^{\circ} \mathrm{C}$, milled to pass through a $0.5 \mathrm{~mm}$ screen, ashed in a microwave furnace, taken up in dilute hydrochloric acid and analysed to determine $\mathrm{P}, \mathrm{K}, \mathrm{Ca}$ and $\mathrm{Mg}$ by ICPAES. The total $\mathrm{N}$ contents of the milled materials were measured using a Leco FP528 nitrogen analyser.

\section{Grape juice and wine characteristics}

Theunsettled must was analysed, and wines weremade, bottled and stored as described by Myburgh (2011). Two wines from each treatment were subjected to sensorial evaluation during August of the year of harvest. Evaluation panels consisted of $\geq 11$ experienced tasters. The parameters evaluated were colour, taste (acidity, fullness and astringency), flavour (aroma intensity, vegetative aroma [asparagus, green bean, green pepper, newly cut grass, tea], berry aroma [blackberry, raspberry, strawberry, black currant], spicy aroma [black pepper, cloves, liquorice, aniseed]) and overall quality. Each parameter was marked on a separate, unstructured $10 \mathrm{~cm}$ line scale marked none/low at one end and prominent/high at the other.

\section{Design and statistical analysis}

A fully randomised design was used in which each of the four treatments (combinations of two soil parent materials [granite, shale] and two rootstocks [101-14Mgt, 110R]) were represented by a single-grapevine plot replicated in each of six blocks. The data were tested for normality (Shapiro \& Wilk, 1965), found to be acceptably distributed and subjected to analysis of variance using the General Linear Model procedure of SAS (Statistical Analysis System) 9.1.3 (SAS Institute Inc., 2008). Data were compared within seasons and over all seasons. Student's t least significant difference (LSD) values were calculated at the $5 \%$ probability (p) level to facilitate comparison between the treatment means (Snedecor \& Cochran, 1980). Means that differed at $\mathrm{p} \leq 0.05$ were considered significantly different.

\section{RESULTS AND DISCUSSION \\ Soil parameters \\ Stone content and soil texture}

The stone content ( $>2 \mathrm{~mm}$ ) of the granite-derived material exceeded that of the shale (Table 1) and was characterised by abundant gravelly quartz crystals and degraded, sub-rounded feldspar fragments, with smaller granules of weathered mica. Lithic (saprolitic) structure was poorly preserved, although occasional fragmented quartz veins were present in the subsoil. In the shale-derived material, the stone consisted of lithic material derived from the 4 to $6 \mathrm{~cm}$ thick

TABLE 1

Particle size distribution and textures of soils developed in parent materials derived mainly from in situ weathering of granite and shale at Nietvoobij, Stellenbosch.

\begin{tabular}{|c|c|c|c|c|c|c|c|}
\hline \multirow[t]{2}{*}{ Parent material } & \multirow[t]{2}{*}{ Stone $(\%)^{(1)}$} & \multicolumn{3}{|c|}{ Sand } & \multirow[t]{2}{*}{ Silt $(\%)^{(2)}$} & \multirow[t]{2}{*}{ Clay $(\%)^{(2)}$} & \multirow[t]{2}{*}{ Texture class } \\
\hline & & Coarse $(\%)^{(2)}$ & Medium (\%) ${ }^{(2)}$ & Fine $(\%)^{(2)}$ & & & \\
\hline Granite & 63 & 22.9 & 9.8 & 33.7 & 17.0 & 16.6 & Sandy loam \\
\hline Shale & 40 & 10.3 & 8.8 & 39.1 & 20.4 & 21.4 & Sandy clay loam \\
\hline
\end{tabular}

\footnotetext{
(1) Stone ( $>2 \mathrm{~mm})$ as fraction of total sample.
}

(2) Percent of soil $(<2.0 \mathrm{~mm})$ fraction. 
beds of immature, formerly phyllitic immature sandstone (metagreywacke) that made up the bedrock (Theron et al., 1992). This material was reddened with oxides near the surface ( 0 to c. $50 \mathrm{~cm}$ ), but kaolinised and pale at greater depths, particularly along the bedding planes. The beds were distorted near the surface by soil creep and broken into friable, easily crumbled fragments. The coarse sand fraction was greater in the granite than in the shale soil (Table 1), as was reported by Van Schoor (2001). Fine sand, silt and clay constituted slightly higher percentages of the shale soil (sandy clay loam) than of the granite (sandy loam) (Table 1). The sand fractions of both soils were dominated by quartz.

\section{Silt and clay mineralogy}

The silt fractions of the granite and shale soils were dominated by quartz (Table 2). Quartz is the most weathering-resistant of the common soil minerals and tends to accumulate in soils, in relative terms, as other minerals break down (Bühmann \& Kirsten, 1991). Because quartz is chemically inert, its role in soil is that of a diluting agent rather than a reactive component. Kaolinite predominates in the clay fractions of the soils in the winter rainfall region (Bühmann et al., 2004b). In the current study, kaolinite was more abundant in the shale than the granite-derived material (Table 2), perhaps reflecting the former abundance of mica and chlorite in the metasediment (Bühmann et al., 2004b). Smectite was absent from the silt fractions of both soils, but present in the clay fractions (Table 2). The clay fraction of the granite contained more smectite than that of the shalederived soil. These mineral assemblages indicate that the granite and shale-derived soils had both reached advanced stages of weathering, and were likely to exhibit similar chemical reactions per unit clay content. Shange (2009) also found that kaolinite was dominant, and quartz and feldspar subdominant, in clay fractions of shale and granite soils from the Stellenbosch wine district (Helderberg). Kaolinite was the dominant clay mineral at a range of sites between Stellenbosch (Helshoogte) and Durbanville (Van Schoor, 2001).

\section{Nutrient status}

The analyses of the soil samples varied inconsistently between seasons, with no apparent trends over time. For this reason, averages, rather than seasonal soil values for the trial period (seasons 2006/07 to 2011/12), are reported in Table 3. In their virgin field states the granite and shale soils were acid, undersaturated in calcium (Ca\%) and low in BP and
Bray II extractable soil K (BK), but adequately saturated with exchangeable $\mathrm{K}$ (K\%) and $\mathrm{Mg}$ (Mg\%) (Table 3), compared to Conradie's (1994) guidelines for grapevine soils. Liming and the addition of P during pre-plant soil preparation, and maintenance liming thereafter, increased the $\mathrm{pH}, \mathrm{Ca} \%$, T-value and BP levels appreciably in both soils as averaged over the trial period, compared with their field levels (Table 3). Over the trial period, $\mathrm{pH}, \mathrm{Ca} \%$ and $\mathrm{Mg} \%$ were close to normal (Conradie, 1994), although liming did not fully neutralise the exchangeable acidity (Table 3). Despite the fact that both soils received similar amounts of superphosphate, average BP levels were higher in the granite than in the shale, probably because the stone content of the shale was lower than that of the granite, resulting in a greater surface area to which the applied P could adsorb. Perhaps for the same reason the maintenance lime requirement of the shale soil was $15 \%$ higher than that of the granite (data not shown).

Bray II K levels in the granite and shale field soils were similar (Table 3) but below the recommended range of 70 to $80 \mathrm{mg} / \mathrm{kg}$ (Conradie, 1994). Average BK levels over the trial period remained close to field level in the granite, but were below field level in the shale soil (Table 3). Liming may also have enabled loosely held $\mathrm{K}$ to move into structural sites (Bühmann et al., 2004b). Liming resulted in $\mathrm{K} \%$ being lower than 3\% in both soils (Table 3), which is below the desired saturation of 4\% (Conradie, 1994). Bray K levels tended to decrease over time, from $64 \mathrm{mg} / \mathrm{kg}$ (virgin field state) to $55 \mathrm{mg} / \mathrm{kg}$ in the granite in 2011 (14\% decrease), and from 67 to $40 \mathrm{mg} / \mathrm{kg}$ (40\% decrease) in the shale soil over the same period (annual averages not shown). The smaller decrease in BK observed in the current study for the granite soil was attributed to the release of structural $\mathrm{K}$ from degrading $\mathrm{K}$ feldspar and mica (Wooldridge, 1988, 1990). Compared to the soils in their field states, liming had only limited effects on CEC (granite, 11.5\% increase; shale, 8.5\% increase), despite having beneficial effects on $\mathrm{pH}$, exchangeable acidity and $\mathrm{Ca} \%$ (Table 3). The abundance of $\mathrm{pH}$-dependent charge sites therefore was low on both soils, which is consistent with clay fractions dominated by kaolinite.

\section{Grapevine parameters}

\section{Leaf water potentials}

Averaged over three seasons, the pre-dawn and mid-day leaf water potentials did not differ significantly between soil $\mathrm{x}$ rootstock treatments when determined at $\Psi_{\mathrm{M}}=-0.07 \mathrm{MPa}$ (Table 4). The pre-dawn $\Psi_{\mathrm{L}}$ values represented stress levels

TABLE 2

Relative proportions of minerals in the silt and clay fractions of soils developed in parent materials derived mainly from the in situ weathering of granite and shale at Nietvoobij, Stellenbosch.

\begin{tabular}{lcccc}
\hline \multirow{2}{*}{ Mineral } & \multicolumn{2}{c}{ Silt fraction } & \multicolumn{2}{c}{ Clay fraction } \\
\cline { 2 - 5 } & Granite (\%) & Shale (\%) & Granite (\%) & Shale (\%) \\
\hline Quartz & $97^{(1)}$ & 93 & - & - \\
Kaolinite & 1 & 2 & 47 & 71 \\
Mica & 0 & 4 & 16 & 14 \\
Feldspar & 2 & 1 & 0 & 0 \\
Smectite & 0 & 0 & 37 & 15 \\
\hline
\end{tabular}

(1) Relative values derived from X-ray diffraction peak heights and expressed as percentages. 


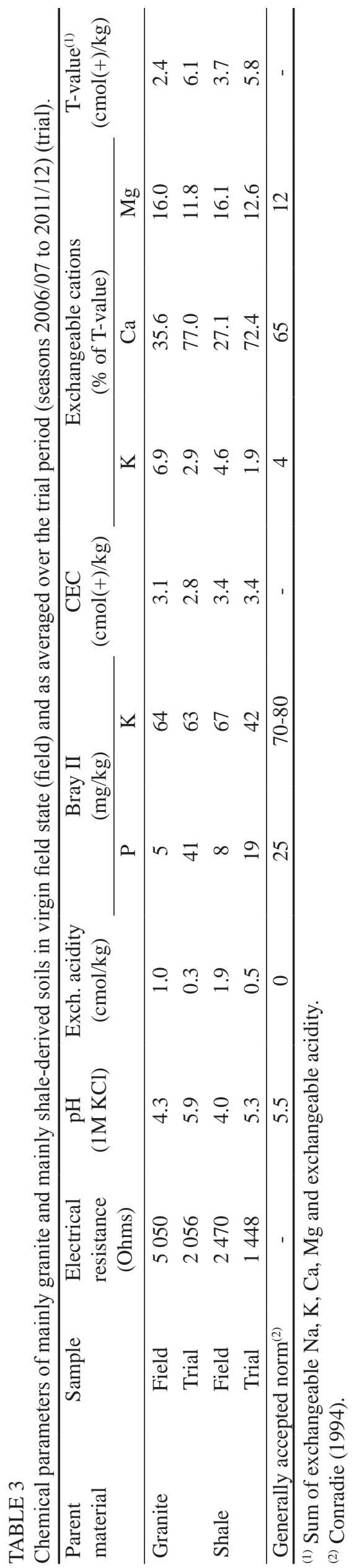

that, compared with stress classes proposed for Merlot by Myburgh (2011), ranged from strong in the granite $x$ 101-14Mgt (GxM), granite x 110R (GxR) and shale x 101$14 \mathrm{Mgt}(\mathrm{SxM})$ treatments, to moderate in the shale $\mathrm{x} 110 \mathrm{R}$ (SxR) treatment. However, at mid-day, $\Psi_{\mathrm{L}}$ did not differ between treatments and corresponded to strong stress. Under the prevailing trial conditions, 101-14Mgt and 110R therefore compared favourably in terms of their ability to sustain midday $\Psi_{\mathrm{L}}$ levels at $\Psi_{\mathrm{M}}$ levels that correspond to strong stress conditions. However, under field conditions, Southey and Archer (1988) have shown that roots of 110R penetrate massive subsoils more effectively, mainly by exploiting cracks, than those of 101-14Mgt. Grapevines grafted onto 110R therefore may perform better than grapevines grafted onto 101-14Mgt in vineyard soils that are compact, assuming that plant-available water is present in the deeper subsoil.

\section{Leaf potassium contents}

Averaged over seasons 2006/07 to 2011/12, neither soil parent material nor rootstock significantly affected leaf blade K concentrations (Table 5). These were within or above the normal range $(0.65 \%$ to $1.30 \%$; Conradie, 1994$)$. In the present trial, seasonal average leaf blade K levels decreased over the trial period, averaging 1.46\% in 2006, 1.22\% in 2009 and $0.86 \%$ in 2011 (data not shown), implying diminishing $\mathrm{K}$ uptake with time. As was also found by Wolpert et al. (2005), the $\mathrm{K}$ concentrations in the petioles were higher than those in the leaf blades (Table 5), and within the normal range of $1.0 \%$ to $2.9 \%$ (Conradie, 1994). Wolpert et al. (2005) showed that petiole $\mathrm{K}$ concentrations in three scion cultivars at bloom were significantly greater in grape vines on $101-14 \mathrm{Mgt}$ than on 110R. A similar pattern was observed in the shale soil (Table 5), but petiole K concentrations did not differ between rootstocks in the granite soil, possibly because the greater availability of $\mathrm{K}$ from the granite soil masked differences in the K uptake capabilities of the rootstocks. Average petiole K concentrations decreased over time in the sequence: 2009/10 (3.63\%) > 2010/11 (1.79\%) > 2011/12 (1.18\%) (data not shown), probably reflecting decreases in K availability. The greater decrease in BK over time in the shale compared to the granite, and the possibly (based on petiole $\mathrm{K}$ concentrations) lesser ability of 110R to take up $\mathrm{K}$ from low-K soils relative to $101-14 \mathrm{Mgt}$, makes it likely that Merlot/110R vineyards on shale soils will require $\mathrm{K}$ supplementation sooner after planting than Merlot/101-14Mgt vineyards. Concentrations of $\mathrm{N}, \mathrm{P}, \mathrm{Ca}$ and $\mathrm{Mg}$, and of the trace elements $\mathrm{Cu}, \mathrm{Fe}, \mathrm{Mn}$, $\mathrm{Zn}$ and $\mathrm{B}$, in the leaf blades and petioles were within normal limits (Conradie, 1994) in all treatments and all seasons (data not shown).

\section{Stem circumference and cane weight}

Average stem circumferences and cane weights over seasons 2007/08 to 2011/12 were lower in the SxR than in all other treatments (Table 5). When extrapolated to 2079 grapevines/ ha, cane weights in the SxM and GxM treatments compared favourably with the c. $4 \mathrm{t} /$ ha reported for Merlot/Ramsey on a fertile soil at Ashton (Lategan \& Howell, 2010a), but decreased in the sequence: GxM, SxM, GxR, SxR (Table 5). Cane weight from the SxR treatment (Table 5) exceeded the weight of $2.4 \mathrm{t} /$ ha observed in an irrigated Merlot/110R vineyard on Oakleaf soil near Stellenbosch (Boshoff, 2010). 
TABLE 4

Effect of soil parent material and rootstock on pre-dawn (04:00) and mid-day (13:00) leaf water potentials $\left(\Psi_{\mathrm{L}}\right)$ and stress levels in Merlot grapevines c. seven days before harvest. Values determined at a mid-day soil water potential of $-0.07 \mathrm{MPa}$. Values presented are averages of three seasons (2009/10 to 2011/12).

\begin{tabular}{lcccccc}
\hline Time of day & Parameter & \multicolumn{3}{c}{ Granite } & & \multicolumn{2}{c}{ Shale } \\
\cline { 3 - 4 } \cline { 5 - 6 } & & $101-14 \mathrm{Mgt}$ & $110 \mathrm{R}$ & & $101-14 \mathrm{Mgt}$ & 110R \\
\hline Pre-dawn & $\Psi_{\mathrm{L}}(\mathrm{MPa})$ & $-0.44 \mathrm{a}$ & $-0.42 \mathrm{a}$ & & $-0.42 \mathrm{a}$ & $-0.38 \mathrm{a}$ \\
& Stress $^{(1)}$ & Strong & Strong & & strong & moderate \\
\multirow{2}{*}{ Mid-day } & $\Psi_{\mathrm{L}}(\mathrm{MPa})$ & $-1.54 \mathrm{a}$ & $-1.52 \mathrm{a}$ & & $-1.56 \mathrm{a}$ & $-1.57 \mathrm{a}$ \\
& Stress $^{(1)}$ & Strong & Strong & & strong & Strong \\
\hline
\end{tabular}

Values in the same row that are followed by the same letter do not differ at $p \leq 0.05$.

(1) Myburgh (2011).

TABLE 5

Effect of soil parent material and rootstock on leaf, vine, berry and canopy parameters in Merlot grapevines grown under semicontrolled conditions. Data are averages for seasons 2006/07 to 2011/12.

\begin{tabular}{|c|c|c|c|c|}
\hline \multirow[t]{2}{*}{ Parameter } & \multicolumn{2}{|c|}{ Granite } & \multicolumn{2}{|c|}{ Shale } \\
\hline & 104-14Mgt & 110R & 104-14Mgt & $110 \mathrm{R}$ \\
\hline Leaf blade K (\%) & $1.16 \mathrm{a}$ & $1.08 \mathrm{a}$ & $1.09 a$ & $1.08 \mathrm{a}$ \\
\hline Petiole K (\%) $)^{(1)}$ & $2.12 \mathrm{~b}$ & 2.23ab & $2.52 \mathrm{a}$ & $1.94 \mathrm{~b}$ \\
\hline Stem circ. (cm) & $10.8 \mathrm{a}$ & $10.2 \mathrm{a}$ & $10.4 \mathrm{a}$ & $9.4 \mathrm{~b}$ \\
\hline Cane weight (kg/vine) & $2.02 \mathrm{a}$ & $1.60 \mathrm{~b}$ & $1.95 \mathrm{a}$ & $1.28 \mathrm{c}$ \\
\hline Cane weight (t/ha) ${ }^{(1)}$ & $4.20 \mathrm{a}$ & 3.33b & $4.06 a$ & $2.67 c$ \\
\hline Leaf layers & $2.22 \mathrm{ab}$ & $2.14 \mathrm{ab}$ & $2.27 \mathrm{a}$ & $1.98 b$ \\
\hline Leaf area ( $\mathrm{cm}^{2} /$ leaf $)$ & $100.8 \mathrm{a}$ & 98.9ab & $97.8 \mathrm{ab}$ & $93.8 \mathrm{~b}$ \\
\hline Leaves/shoot & $58.9 a$ & $47.0 \mathrm{~b}$ & $54.2 \mathrm{ab}$ & 49.9ab \\
\hline Shoots/vine & $20.3 b$ & 22.3a & $20.0 \mathrm{~b}$ & $19.5 b$ \\
\hline Total leaf area (m²/vine) $)^{(2)}$ & $12.05 a$ & $10.37 \mathrm{bc}$ & $10.60 \mathrm{~b}$ & $9.13 c$ \\
\hline Yield (kg/vine) & $5.94 \mathrm{ab}$ & $6.60 \mathrm{a}$ & $5.21 b$ & $5.32 b$ \\
\hline Yield (t/ha, 2079 vines/ha) $)^{(1)}$ & 12.3ab & $13.7 \mathrm{a}$ & $10.8 \mathrm{~b}$ & $11.1 b$ \\
\hline Yield (t/ha, 3333 vines/ha) $)^{(1)}$ & 19.8ab & 22.0a & $17.4 \mathrm{~b}$ & $17.7 b$ \\
\hline Bunch weight (g/bunch) & $169 b$ & $180 \mathrm{ab}$ & $170 \mathrm{~b}$ & $191 \mathrm{a}$ \\
\hline Bunches/vine & 35.1ab & 36.8a & $32.6 b c$ & $31.4 \mathrm{c}$ \\
\hline Berries/bunch & 180.9a & 185.7a & $153.4 b$ & $154.0 \mathrm{~b}$ \\
\hline Berry weight (g/berry) & $1.26 \mathrm{a}$ & $1.21 \mathrm{a}$ & $1.29 \mathrm{a}$ & $1.33 a$ \\
\hline
\end{tabular}

Values in the same row that are followed by the same letter do not differ at $p \leq 0.05$.

(1) Extrapolated from average yield/vine.

(2) Calculated from average single leaf area, average number of leaves per shoot and average number of shoots per vine.

This, in turn, exceeded the 1.3 to 1.9 t/ha cane weights reported by Myburgh (2011) for a Merlot/99R vineyard (3 333 vines/ha) near Wellington.

Across both soils, average cane weights from Merlot/101-14Mgt exceeded those from Merlot/110R by $38 \%$, which agrees with the results of Wolpert et al. (2005). Cane weights were $12 \%$ greater from the granite than from the shale soil (Table 5), perhaps in response to the higher $\mathrm{K}$ content of the granite soil over the trial period. The percentage difference between rootstocks exceeded that between soils, suggesting that the effect of rootstock on vegetative growth exceeds that of the soil.

Conradie (1983) reported that, although root and shoot dry masses of pot-grown grapevines on 101-14Mgt exceeded those on $110 \mathrm{R}$ in a Clovelly soil that had been limed to $\mathrm{pH}$ 5.8, 110R produced greater root and shoot masses than 101-14Mgt on the same soil in both its unlimed field state (pH 3.8), and after liming to $\mathrm{pH}$ 4.6. Similarly, trunk dry masses from 110R exceeded those from 101-14Mgt on the unlimed soil ( $\mathrm{pH}$ 3.8) and the soil that had been limed to $\mathrm{pH}$ 4.6. No differences in trunk dry mass that could be attributed to rootstock were observed at $\mathrm{pH}$ 6.0. Vegetative growth in grapevines on 101-14Mgt therefore is suppressed to a greater extent by soil acidity than on 110R (Conradie, 1983). In the present trial, sufficient acidity may have remained in the shale soil to contribute to the differences in cane weight between the soil x rootstock treatments (Table 5). 


\section{Canopy}

On the shale soils, the canopies of Merlot grapevines on 110R were thinner (fewer leaf layers) than those on 101-14Mgt (Table 5). Shoot numbers per vine were higher in the GxR compared to the other treatments. At the low $\mathrm{K}$ saturations that prevailed in the shale compared to the granite soil, 110R may have been less able than 101-14Mgt to maintain adequate $\mathrm{K}$ concentrations in the mature leaves at the base of the shoot. Potassium is highly mobile in plants (Mengel \& Kirkby, 2001). In K-deficient apple orchards, K is recycled from old leaves at the base of the shoot, which may then abscise, to newer leaves higher up the shoot. Consequently, $\mathrm{K}$ concentrations in the newer leaves often remain at normal levels, despite a low overall $\mathrm{K}$ status in the tree. On the granite soils, 101-14Mgt produced more leaves per shoot than 110R, and the GxM treatment produced larger leaves than SxR. Total leaf area per grapevine decreased in the sequence: GxM, SxM, GxR, SxR. Total leaf area in the granite treatments was $13.6 \%$ greater on average than in the shale treatments, and $16.2 \%$ greater in Merlot vines on 101-14Mgt than on 110R.

In terms of the vegetative vine parameters - stem circumference, cane weight and total leaf area per grapevine, the Merlot grapevines on granite soil and 101-14Mgt rootstock outperformed the Merlot vines on shale soil and 110R (Table 5). This difference was attributed to greater effectiveness on the part of $101-14 \mathrm{Mgt}$, relative to $110 \mathrm{R}$, under conditions of low soil K availability. Water availability did not detrimentally affect vegetative performance in the SxR treatment, as the pre-dawn leaf water stress in this treatment tended to be lower than in the other treatments (Table 4).

\section{Yield}

Average yields from the GxR treatment significantly exceeded those from the SxM and SxR treatments (Table 5). Yields from the GxM and GxR treatments did not differ at $\mathrm{p} \leq 0.05$. Analysis of yield and stem weight on a seasonal basis indicated that average yields and stem weights were lower, by $28.7 \%$ and 28.9\% respectively, in 2011/12 and in 2010/11 (data not shown). Since the K saturations of the granite and shale soils ( $2.9 \%$ and $1.9 \%$ respectively) were below the desired level of 4\% (Conradie, 1994) in 2011/12, the lower yields and cane masses in 2011/12 were probably due to $\mathrm{K}$ deficiency. Extrapolated to a planting density of 2079 vines/ha, the average yield of $12.0 \mathrm{t} / \mathrm{ha}$ (Table 5) exceeded the $9.6 \mathrm{t} / \mathrm{ha}$ obtained from Merlot in an irrigated Oakleaf soil (Boshoff, 2010). The 19.8 t/ha calculated in the current trial (Table 5) also exceeded the four-season average of c. $13.1 \mathrm{t} /$ ha reported for a 3333 grapevines/ha vineyard (Myburgh, 2011). On a yield/vine basis, the yields, which ranged from 5.209 to $6.603 \mathrm{~kg} / \mathrm{vine}$ (Table 5), also exceeded the $3.915 \mathrm{~kg} /$ vine average yield found by Myburgh (2011). Although the yields observed in the current study exceeded those of Boshoff (2010) and Myburgh (2011), they were low compared with the c. 20 t/ha that was obtained from a fertile alluvial soil in the Breede river valley (Lategan \& Howell, 2010a, 2010b). This suggests that the yields observed in the current study could have been sub-optimal due to $\mathrm{K}$ deficiency, especially in the shale-derived soil.

\section{Bunches}

Compared to an average bunch weight of $122 \mathrm{~g}$ in the irrigated Merlot vines found by Myburgh (2011), all the treatments produced high bunch weights (Table 5). Bunch weights were lower in the GxM and SxM treatments than in the SxR treatment. This latter treatment was also characterised by the lowest observed number of bunches per grapevine, implying a negative relationship in the SxR treatment between bunch mass and bunch number. Average bunch numbers in GxR exceeded those in the shale treatments. Relative to the average of 33.0 bunches per vine observed by Myburgh (2011) the numbers of bunches produced per vine on the granite treatments were high (Table 5). Rootstock had little ( $<1 \%$ ) effect on bunch number. Numbers of berries per bunch exceeded the average of 91.0 berries per bunch reported by Myburgh (2011), with the granite treatments associated with more berries per bunch than the shale treatments (Table 5). Rootstock had no effect on the number of berries per bunch. Weights of individual berries were not affected by the individual treatments (Table 5). This observation agreed with that of Myburgh (2011).

\section{Grape juice}

The applied treatments had few significant effects on grape juice composition (data not shown). Juice $\mathrm{pH}$ ranged from 3.30 to 3.42, which was within the optimum range of 3.3 to 3.7 for red wines (Mpelasoka et al., 2003). Nevertheless, acidity tended to be greater in the shale than the granite treatments (averages of $6.4 \mathrm{~g} / \mathrm{L}$ and $5.9 \mathrm{~g} / \mathrm{L}$ respectively), and $\mathrm{N}$ was slightly lower (159 $\mathrm{mg} / \mathrm{L})$ in juice from vines on 101-14Mgt than from those on 110R (187 mg/L) (Table 5). Potassium concentrations averaged $882 \mathrm{mg} / \mathrm{L}$ and $894 \mathrm{mg} / \mathrm{L}$ in juice from the granite and shale soils respective, $934 \mathrm{mg} / \mathrm{L}$ in juice from the Merlot/101-14Mgt vines, and $842 \mathrm{mg} / \mathrm{L}$ in juice from the Merlot/110R vines. The greatest contrast was between the 101-14Mgt and 110R rootstocks on the granite soil, which averaged 961 and $803 \mathrm{mg} / \mathrm{L}$ respectively. This difference was significant, and supports the results of Wolpert et al. (2005). That the rootstocks in the present trial had different effects on juice but not petiole $\mathrm{K}$ on the granite soil was attributed to the greater sink strength of berries relative to grapevine leaves (Mpelasoka et al., 2003; Wolpert et al., 2005)

\section{Sensory evaluation}

Fullness was greater in wines from the GxM treatment than those from the GxR and SxR treatments (Table 6). Astringency was more prominent in the wine from the GxM than the GxR and SxM treatments. Overall quality in wines from the GxM treatment exceeded that from the SxR treatment. Wine quality therefore was highest from the GxM treatment (i.e. the combination of highest soil $\mathrm{K}$ content and the rootstock with the higher capacity to maintain adequate $\mathrm{K}$ concentrations in the petiole (according to Wolpert et al., 2005)). Conversely, wine quality was lowest in the combination of lower $\mathrm{K}$ soil and low K-uptake rootstock (i.e. SxR) (Table 6). Rootstocks having different genetic backgrounds may therefore not perform equally well in different soils (Southey \& Archer, 1988).

The low CECs, which were attributed to the abundance 
TABLE 6

Effect of soil parent material and rootstock on sensory characteristics of wines produced from Merlot grapevines grown under semi-controlled conditions. Data measured on an unstructured line scale and averaged over seasons 2006/07 to 2011/12.

\begin{tabular}{|c|c|c|c|c|}
\hline \multirow[t]{2}{*}{ Parameter } & \multicolumn{2}{|c|}{ Granite } & \multicolumn{2}{|c|}{ Shale } \\
\hline & 104-14Mgt & $110 \mathrm{R}$ & 104-14Mgt & $110 \mathrm{R}$ \\
\hline Colour & $6.38 a$ & $6.36 a$ & 6.30a & $6.20 \mathrm{a}$ \\
\hline Acidity & $5.22 \mathrm{a}$ & $5.00 \mathrm{a}$ & $5.09 a$ & $5.32 \mathrm{a}$ \\
\hline Fullness & $5.14 \mathrm{a}$ & $4.73 b$ & $4.81 \mathrm{ab}$ & $4.62 b$ \\
\hline Astringency & $3.87 \mathrm{a}$ & $3.54 c$ & 3.63bc & 3.77ab \\
\hline Aroma intensity & $5.97 a$ & $5.84 \mathrm{a}$ & 5.91a & $5.74 a$ \\
\hline Vegetative aroma & $4.17 \mathrm{a}$ & $4.19 \mathrm{a}$ & $4.23 a$ & $4.16 \mathrm{a}$ \\
\hline Berry aroma & $4.82 \mathrm{a}$ & 4.63a & $4.54 a$ & 4.39a \\
\hline Spicy aroma & $3.71 \mathrm{a}$ & 3.56a & $3.80 \mathrm{a}$ & $3.62 \mathrm{a}$ \\
\hline Overall quality & $5.26 \mathrm{a}$ & 4.99ab & $4.95 \mathrm{ab}$ & $4.62 \mathrm{~b}$ \\
\hline
\end{tabular}

Values in the same row that are followed by the same letter do not differ at $p \leq 0.05$.

of kaolin (a clay mineral that has a minimal capacity to buffer $\mathrm{K}$ ), implies that applied (fertiliser) $\mathrm{K}$ is likely to be highly plant available, leading to luxury consumption and poor wine quality (Iland, 1988; Mpelasoka et al., 2003; Deloire, 2010) in the short term, but easily leached, resulting in the onset of $\mathrm{K}$ deficiency over the longer term (Wooldridge, 1988).

\section{CONCLUSIONS}

Parent rock type, as reflected in the highly weathered, kaolin-dominated parent materials of the mainly granite and shale-derived soils of the western coastal foreland of the Western Cape, does not affect vine performance and wine characteristics consistently in Merlot grapevines on 101-14Mgt and 110R rootstocks. Interaction between soil parent material and rootstock signifies a higher level of complexity than can be explained by differences in soil parent material alone, and illustrates the need to select rootstocks that are adapted to both the scion and the prevailing soil conditions. The highly weathered soil parent materials in vineyards on the western coastal foreland are unlikely to be useful for demarcation purposes, but should be considered when selecting rootstocks for Merlot. The combination of soil derived mainly from weathered granite, and the 101-14Mgt rootstock is likely to produce higher quality Merlot wine, and more vigorous grapevines, than that of Merlot/110R vines on weathered shale, providing that no constraining soil factors are present and no $\mathrm{K}$ is applied. In existing Merlot vineyards, analysis-based $\mathrm{K}$ fertilisation should be considered where performance is, or becomes, weak. Benefits will probably be obtained from $\mathrm{K}$ fertilisation sooner after planting in Merlot/110R grapevines in shalederived soils than in Merlot/101-14Mgt vineyards in granite soils. In neither granite nor shale-derived soils is the rate or continuity of supply of $\mathrm{K}$ from native sources likely to be adequate to maintain reasonable performance in Merlot grapevines for more than a limited period. In open vineyards, differences in cultural practice are likely to override the effects of soil parent material.

\section{LITERATURE CITED}

Alexiades, C.A. \& Jackson, M.L., 1966. Quantitative clay mineralogical analysis of soils and sediments. Clays and Clay Minerals 14, 35-52.

Bonnardot, V., Carey, V. \& Rowswell, D., 2011. Observed climatic trends in Stellenbosch: Update and brief overview. Wynboer Technical Journal, 100-104.

Boshoff, C.J., 2010. A study of the interaction between grapevine vigour and water stress for Vitis vinifera L. cv. Merlot noir in Stellenbosch. Thesis, Stellenbosch University, Private Bag X1, 7602 Matieland (Stellenbosch), South Africa.

Bühmann, C., Escott, B.J. \& Hughes, J.C., 2004a. Soil mineralogy research in South Africa. 1978 to 2002 - a review. S. Afr. J. Plant Soil 21, 316-329.

Bühmann, C., Nell, J.P. \& Samadi, M., 2004b. Clay mineral associations in soils formed under Mediterranean-type climate in South Africa. S. Afr. J. Plant Soil 21, 166-170.

Conradie, W.J., 1983. Liming and choice of rootstocks as cultural techniques for vines in acid soils. S. Afr. J. Enol. Vitic. 4, 39-44.

Conradie, W.J., 1994. Vineyard fertilisation. ARC-Fruit, Vine and Wine Research Institute, Nietvoorbij, Private Bag X5026, 7599 Stellenbosch, South Africa.

Deloire, A., 2010. Berry development - an overview. Part 7. Berry and organic acids. Wynboer Technical Yearbook, pp. 112 - 113.

Fey, M., 2010. Soils of South Africa. Cambridge, Cape Town.

Floris, B. \& Uren, N., 2011. Status of wine grape vines as on 31 December 2011. South African Wine Industry Information and Systems, Paarl, South Africa.

Iland, P.G., 1988. Grape berry ripening: The potassium story. Australian Grapegrower Winemaker January, 22-24.

Kotzé, W.A.G., 2001. Voeding van bladwisselende vrugtebome, bessies, neuter en ander gematigde klimaat gewasse in Suid-Afrika. ARC InfruitecNietvoorbij, Private Bag X5026, 7599 Stellenbosch, South Africa.

Lambrechts, J.J.N., 1983. Soils, soil processes and soil distribution in the Fynbos region: An introduction. In: Deacon, H.J., Hendey, Q.B. \& Lambrechts, J.J.N. (eds). Fynbos palaeoecology: A preliminary synthesis. South African national scientific programmes report no. 75, Council for Scientific and Industrial Research, Pretoria. pp. $61-69$. 
Lategan, E.L. \& Howell, C.L., 2010a. The partial rootzone drying (PRD) of Merlot in the Breede River Valley (Part 1): Irrigation volumes, plant water stress and vigour. Wynboer Technical Yearbook, 19-21.

Lategan, E.L. \& Howell, C.L., 2010b. The partial rootzone drying (PRD) of Merlot in the Breede River Valley (Part 2): Production, water use efficiency and wine quality. Wynboer Technical Yearbook, 22-24.

Mengel, K. \& Kirkby, E.A., 2001 (5 $5^{\text {th }}$ ed). Principles of plant nutrition. Kluwer, Dordrecht.

Mpelasoka, B.S., Schachtman, D.P., Treeby, M.T. \& Thomas, M.R., 2003. A review of potassium nutrition in grapevines with special emphasis on berry accumulation. Aus. J. Grape Wine Res. 9, 154-168.

Myburgh, P., 2010. Practical guidelines for the measurement of water potential in grapevine leaves. Wynboer Technical Journal, 11-13.

Myburgh, P.A., 2011. Response of Vitis vinifera L. cv. Merlot to low frequency drip irrigation and partial root zone drying in the Western Cape Coastal Region - Part 1. Soil and plant water status. S. Afr. J. Enol. Vitic. 32, 89-103.

Non-Affiliated Soil Analysis Work Committee, 1990. Handbook of standard soil testing methods for advisory purposes. Soil Sci. Soc. South Africa, P.O. Box 30030, 0132 Sunnyside, South Africa.

Partridge, T.C. \& Maud, R.R., 1987. Geomorphic evolution in southern Africa since the Mesozoic. S. Afr. J. Geol. 90, 179-208.

SAS Institute Inc., 2008. SAS/STAT ${ }^{\circledR} 9.2$ user’s guide. SAS, Campus Drive, Cary NC 27513, North Carolina.

Scholander, P.F., Hammel, H.T., Bradstreet, E.D. \& Hemmingsen, E.A., 1965. Sap pressure in vascular plants. Science 148, 339-346.

Shange, P.L., 2009. Nutritional status of geologically different vineyards in Helderberg. Thesis, Stellenbosch University, Private Bag X1, 7602 Matieland (Stellenbosch), South Africa.

Shapiro, S.S. \& Wilk, M.B., 1965. An analysis of variance test for normality (complete samples). Biometrika 52, 591-611.

Snedecor, G.W. \& Cochran, W.G., 1980 (7th ed). Statistical methods. Ames, Iowa. Iowa State University Press.
Söhnge, A.P.G., 1991. Alluvial history of the Eerste River, Stellenbosch. S Afr. J. Geol. 94, 299-312.

Soil Classification Working Group, 1991. Soil classification: A taxonomic system for South Africa. Memoirs of the Agricultural Natural Resources of South Africa No. 15, Dept of Agri. Develop., Private Bag X144, Pretoria, South Africa.

Southey, J.M. \& Archer, E., 1988. The effect of rootstock cultivar on grapevine root distribution and density. In: Van Zyl, J.M. (ed). The grapevine root and its environment. Viticultural and Oenological Research Institute, Stellenbosch. Republic of South Africa Department of Agriculture and Water Supply technical communication no. 215. pp. 57 - 73.

Theron, J.N., Gresse, P.G., Siegfried, H.P. \& Regers, J., 1992. The geology of the Cape Town area. Explanation of sheet 3318. Department of Mineral and Energy Affairs, Pretoria, South Africa.

Van Schoor, L.H., 2001. Geology, particle size distribution and clay fraction mineralogy of selected vineyard soils in South Africa and the possible relationship with grapevine performance. Thesis, Stellenbosch University, Private Bag X1, 7602 Matieland (Stellenbosch), South Africa.

Van Zyl, J.L., 1988. The grapevine root and its environment. Republic of South Africa Department of Agriculture and Water Supply technical communication no. 215, Viticultural and Oenological Research Institute, Stellenbosch.

Wilson, M.J., 1999. The origin and formation of clay minerals in soils: Past, present and future perspectives. Clay Minerals 34, 7-25.

Wolpert, J.A., Smart, D.R. \& Anderson, M., 2005. Lower petiole potassium concentration at bloom in rootstocks with Vitis berlandieri genetic background. Am. J. Enol. Vitic. 56, 163-169.

Wooldridge, J., 1988. The potassium supplying power of certain virgin upland soils of the Western Cape. Thesis, Stellenbosch University, Private Bag X1, 7602 Matieland (Stellenbosch), South Africa.

Wooldridge, J., 1990. Effect of liming and parent material on the potassium quantity/intensity relationships of some upland soils of the Western Cape. S. Afr. J. Plant Soil 7, 62-67. 